\section{Director’s Foreword}

\section{Whitney W. Donhauser}

Ronay Menschel Director \&ั

President of the Museum of the City of New York
$\mathrm{N}$ ew York City is known as the nation's finance capital, media capital, arts capital-even as the "capital of the world." But in important ways, it is also the capital of labor. New York was an incubator of the nation's trading economy, its industrial economy, and its financial economy, and each of these was made possible by the brains, skills, and muscle of the city's working people. Here they incubated a variety of labor movements, from the first organizations of craftsmen in the era of the Revolution to the Workingmen's Party of the 1820s, to the American Federation of Labor and the International Ladies' Garment Workers' Union, and on to the Household Technicians of America. The nation's very first Labor Day was held in New York City on September 5 , 1882, and today, well over a century later, new organizations like worker centers are re-defining workers' movements yet again.

The Museum of the City of New York's signature exhibition, New York at Its Core, argues that New York City is defined by four wordsmoney, diversity, density, and creativity-and the city's history of labor movements has all of these in abundance, as the chapters in this volume show. It is a story full of human drama and struggle, success and scandal, pathos and politics, and it shows how the city's character has been shaped by generations of people fighting for the independence, dignity, and the wellbeing of themselves and their communities.

\section{City of Workers, City of Struggle: How} Labor Movements Changed New York began life as a 2019 exhibition of the same name at the Museum of the City of New York. Our gratitude goes to The Puffin Foundation whose generous support made the exhibition and its companion publication possible. Perry, Gladys, and Neal Rosenstein's commitment to preserving the legacy of New York's labor history as well as that of generations of activists through our ongoing exhibition Activist New York and its companion programming, publication, and online resources for students and educators enable us to reach countless people with stories that might otherwise have been forgotten. The Puffin Foundation has been a champion of labor rights and causes, and their vision and dedication is inspiring and deeply appreciated.

The exhibition is presented in collaboration with the Kheel Center at the School of Industrial and Labor Relations at Cornell University and the Tamiment Library \& Robert F. Wagner Labor Archives at NYU. We are grateful for the leadership of Curtis Lyons and the assistance of Steven Calco at Kheel Center and for the leadership of Timothy Johnson and the assistance of Danielle Marie Nista at Tamiment for making access to their remarkable, rich collections possible. Additional support for this publication was provided by Furthermore: a program of the J. M. Kaplan Fund, and other generous donors.

Huge thanks go to our editor, Dr. Joshua B. Freeman, who shepherded an impressive group of contributing authors with care, vision, and good humor, working closely with the Museum's Deputy Director and Chief Curator Dr. Sarah M. Henry and Director of Publications Susan Gail Johnson. Exhibition curator Steven $H$. Jaffe contributed editorial assistance and insight as well as lending his research to the book's rich and lively illustrations-drawn from the collections of the Museum and beyond. A dynamic design by Michael Gericke, Yeryung Ko and Alex Mäkäräinen, with the support of Amanda Kesner Walter, at Pentagram reflects the vibrant stories told on 

its companion exhibition-are participants in

a vital ongoing reexamination of American labor history that continues to transform our understanding of that history. By expanding the very terms of scholarship to probe the complex relationships among organized labor, politics, economic change, cultural expression, and urban governance; by including previously ignored groups of working people; by widening the definition of labor activism to explore movements outside mainstream unions; and by examining the cultural and social lives of working women, men, children, and families, these historians and social scientists are changing how we view our own New York and how we assess what is at stake in the city's future. We thank them, and we hope you enjoy the fruits of their labor contained within the covers of this book. 


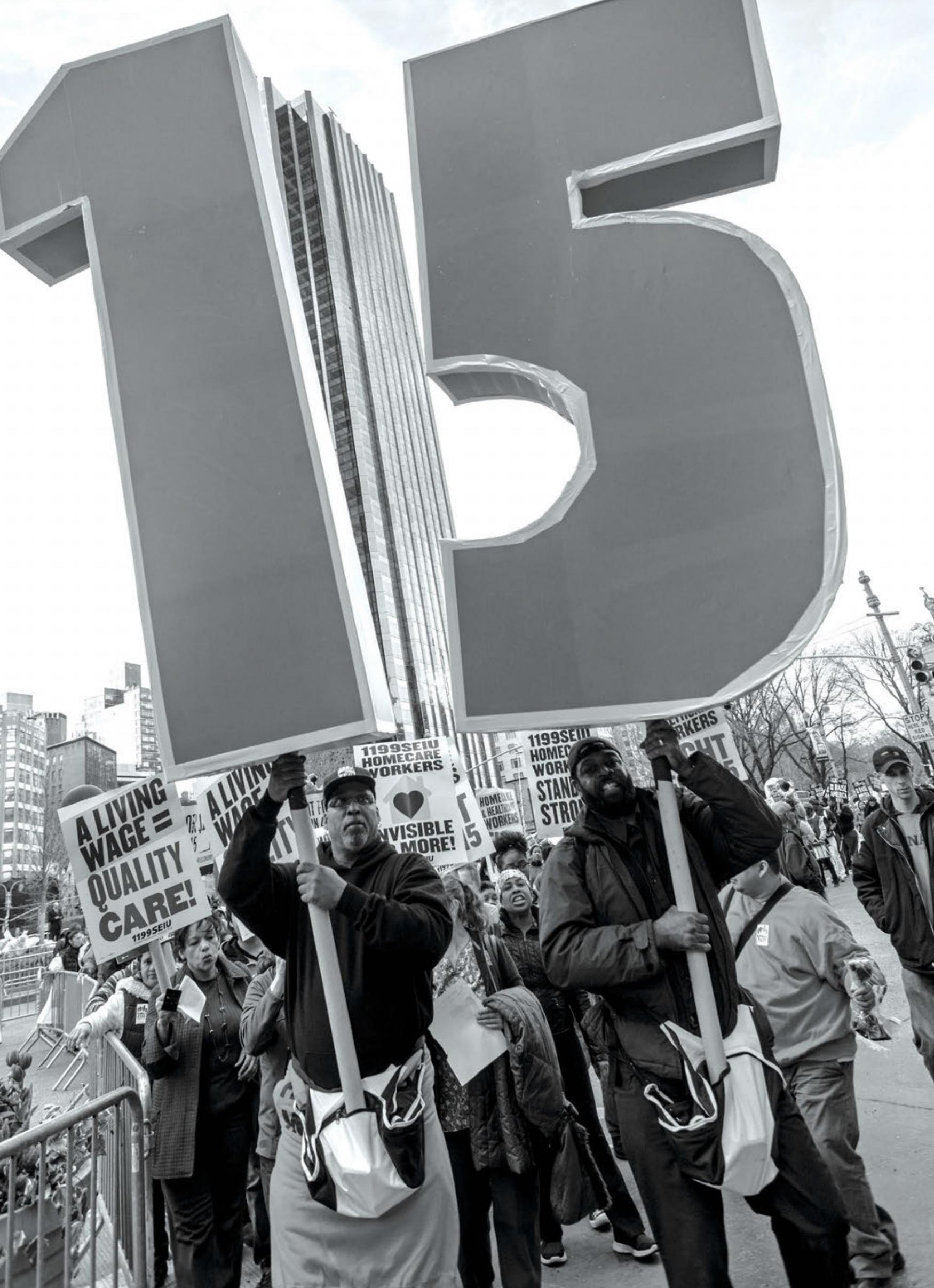




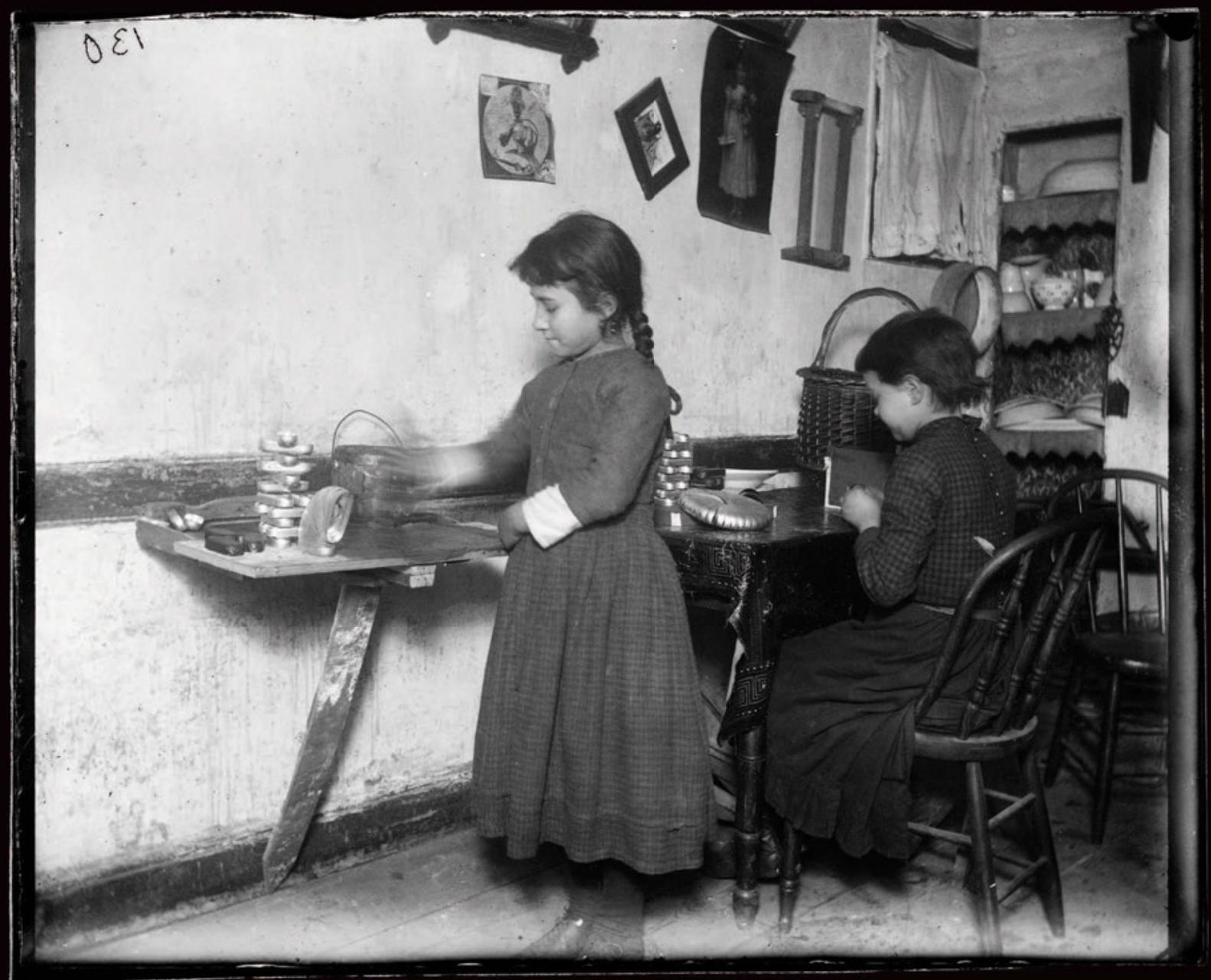

